\title{
Pengaruh Working Capital Management Terhadap Profitabilitas Perusahaan : Literatur Review
}

\author{
Dedi Supiyadi ${ }^{1}$, Diah Dianti Rohani ${ }^{2}$, Dodi ${ }^{3}$, dan Rini Kurniawati ${ }^{4}$ \\ ${ }^{1}$ Dosen Program Studi Administrasi Bisnis Universitas Sangga Buana YPKP \\ ${ }^{234}$ Mahasiswa Magister Manajemen Universitas Pendidikan Indonesia \\ 1'dedi.upiyadi@usbypkp.ac.id
}

\begin{abstract}
ABSTRAK
Tujuan studi ini adalah untuk mereview penelitian tentang pengruh working capital management (WCM) terhadap profitabilitas perusahaan. Metode yang digunakan yaitu traditional review, dengan mereview 25 jurnal intenasional yang diterbitkan pada jurnal internasional bereputasi. Dari ulasan yang dilakukan diketahui bahwa sebagian besar peneliti menggunakan metode empiris dalam menganalisis pengaruh working capital management dengan profitabilitas. Hasil yang diperoleh dari sebagian besar penelitian mengungkapkan bahwa WCM memiliki peranan penting bagi profitabilitas perusahaan.
\end{abstract}

Kata Kunci: Working Capital Management, Profitabilitas

\begin{abstract}
The purpose of this study is to review research on the effect of working capital management (WCM) on firm profitability. The method used is traditional review, by reviewing 25 international journals published in reputable international journals. From the reviews conducted, most researchers use empirical methods in analyzing the effect of working capital management on firm profitability. The result indicate that working capital management has important role to firm's profitability.
\end{abstract}

Keywords: Working Capital Management, Profitabily 


\section{PENDAHULUAN}

Working Capital Management (WCM) merupakan bagian penting dari manajemen keuangan dan memberikan kontribusi signifikan terhadap penciptaan kekayaan suatu perusahaan karena langsung mempengaruhi profitabilitas dan likuiditas organisasi (Raheman dan Nasr, 2007). Working capital merupakan faktor penentu berjalannya kegiatan operasional dalam jangka pendek dalam perusahaan. Oleh karena itu, banyak perusahaan yang memiliki kas cukup besar diinvestasikan dalam working capital dan sebagian dijadikan hutang jangka pendek sebagai bentuk pembiayaan (Deloof, 2003).

Working capital management mengandung keseimbangan proporsi komponen working capital yaitu hutang (payable), inventory, piutang (receivable) serta penggunaan kas secara efektif yang digunakan untuk operasional bisnis setiap hari (Agha, 2014). Optimisasi yang tepat dari working capital berarti meminimalkan kebutuhan working capital dan mendapatkan pendapatan secara maksimal (Ganesan, 2007).

Tujuan utama dari sebuah perusahaan yaitu untuk memaksimalkan keuntungan. Tetapi menjaga likuiditas perusahaan juga merupakan tujuan yang penting. Masalahnya adalah meningkatkan keuntungan pada biaya likuiditas dapat memberikan masalah serius bagi perusahaan. Dengan demikian, strategi perusahaan harus mempertahankan keseimbangan antara dua tujuan tersebut (Agha,2014).

Penelitian-penelitian sebelumnya lebih banyak menganalisis terhadap perusahaan-perusahaan besar, tetapi saat ini banyak juga penelitian yang menganalisis perusahaan kecil dan menengah (UKM). Pengelolaan current asset dan liabilitas juga sangat penting pada perusahaan kecil dan menengah (Teruel, Solano, 2007). Pada bagian selanjutnya akan dilakukan analisis terhadap 25 jurnal internasional yang mengkaji tentang pengaruh working capital manajement terhadap profitabilitas perusahaan, hasil analisis dari journal ini akan menunjukan apakah Working Capital Management merupakan faktor penting dalam meningkatkan profitabilitas perusahaan.

\section{TINJAUAN PUSTAKA}

\section{Working Capital Management}

Working Capital Management penting untuk kesehatan keuangan baik untuk perusahaan kecil dan menengah maupun perusahaan besar (Sings dan Kumar, 2013). Jumlah yang diinvestasikan dalam working capital sebanding dengan total asset yang digunakan, sehingga sangat penting untuk memastikan keduanya dimanfaatkan secara efektif (Padachi 2006 dalam Sings dan Kumar, 2013).

Working capital yaitu keseimbangan antara current assets dan current liabilities (Pass dan Pike, 1984 dalam Sings dan Kumar, 2013). Working capital dibagi menjadi 2 kategori yaitu gross working capital dan net working capital. Gross working capital adalah jumlah total seluruh asset lancar (current assets), sedangkan net working capital adalah perbedaan antara asset lancar (current asset) dengan kewajiban lancar (current liabilities). Current assets terdiri dari stok atau inventory (bahan baku + barang setengah jadi + barang jadi yang menunggu penjualan dan pengiriman), piutang (tagihan yang belum dibayar yang keuntungannya telah dicatat pada neraca), hutang (dari supplier), kas dan sekuritas jangka pendek. Current liabilities terdiri dari pembayaran kredit (bahan baku dan lainnya), bank overdraft, pinjaman jangka pendek lainnya, pajak, deviden dan bunga.

\section{Pengukuran Working Capital Management}

Working capital management berada sebagai variabel independen. Pengukuran yang populer dalam working capital management yaitu Cash Conversion Cycle (CCC). CCC adalah jeda waktu antara 
pengeluaran untuk pembelian bahan baku dan hasil penjualan barang jadi (Deloof, 2003). Hampir seluruh jurnal yang direview menggunakan CCC. Semakin lama siklus ini berarti lebih banyak investasi dalam working capital sehingga menurunkan CCC seminimum mungkin, pada umumnya akan meningkatkan profitabilitas. $\mathrm{CCC}$ diperoleh dengan menggunakan rumus sebagai berikut :
$\mathrm{CCC}=$ no. of days inventories + no. days accounts receivable - no. of days accounts payable

No. of days accounts receivable dihitung dengan rumus [piutang dangang $\mathrm{x}$ $365]$ /penjualan. No. of days inventories dihitung dengan [persediaan x 365]/biaya penjualan. No. of days accounts payable dihitung dengan [hutang dagang $\mathrm{x}$ 365]/pembelian.

\section{Pengukuran Profitabilitas}

Profitabilitas pada penelitian ini berada sebagai variabel dependen. Berdasarkan hasil review jurnal, sebagian besar peneliti dalam mencari profitabilitas perusahaan menggunakan Return on Assets (ROA). ROA diperoleh dengan menggunakan rumus sebagai berikut :

ROA = Operating Profit/Total Asset

Dalam mencari hubungan antara working capital management dengan profitabilitas, sebagian besar peneliti memberikan variabel kontrol pada penelitiannya. Variabel kontrol yang biasa digunakan yaitu SIZE (skala perusahaan),

\section{METODOLOGI}

Metode yang digunakan dalam melakukan literature review ini adalah traditional review, dimana jurnal-jurnal ilmiah yang direview dipilih sendiri oleh para peneliti pada satu topik penelitian yaitu hubungan antara working capital management dengan profitabilitas perusahaan, dan dipilih berdasarkan pengetahuan dan pengalaman yang dimiliki oleh seorang peneliti. Sumbersumber tulisan yang dapat dijadikan sebagai bahan studi literatur atau studi pustaka di antaranya adalah buku-buku teoritis dan jurnal-jurnal ilmiah yang telah terakreditasi.

Langkah-langkah yang dilakukan dalam studi literatur atau studi pustaka pada penelitian ini adalah:

1. Mencari jurnal yang relevan yang telah terakreditasi secara internasional yang meneliti juga mengenai pengaruh struktur modal terhadap profitabilitas sebanyak 25 jurnal.

2. Mengkaji isi dari jurnal-jurnal tersebut diantaranya tujuan penelitiannya, metodologi penelitiannya, dan hasil penelitiannya.

3. Membandingkan hasil penelitian antara jurnal yang satu dengan jurnal yang lainnya, karena hasil penelitian dari setiap jurnal akan terdapat perbedaan.

4. Setelah membandingkan hasil penelitian dari setiap jurnal tersebut, selanjutnya adalah menyimpulkan yang pada akhirnya akan melahirkan hipotesis yang kemudian dapat diuji secara empirik pada penelitian selanjutnya.

\section{HASIL DAN PEMBAHASAN}

Jurnal yang direview pada penelitian ini berjumlah 25 jurnal internasional yang berasal dari tahun 2003 - 2016. Keseluruhan jurnal membahas mengenai hubungan antara working capital management dengan profitabilitas perusahaan. 25 jurnal tersebut terbagi menjadi 20 jurnal dengan objek perusahaan yang berskala besar non keuangan (biasanya terdaftar dalam bursa efek) dan 5 jurnal membahas perusahaan kecil dan menengah (UKM).

Hasil penelitian dalam kajian ini disajikan secara lengkap pada Matrik dibawah ini yang mengambarkan mengenai tujuan penelitian, metode yang digunakan serta hasil penelitian yang dilakukan di berbagai negara sebagai berikut : 


\begin{tabular}{|c|c|c|c|c|c|c|}
\hline NO & PENELITI & JUDUL & OBJEK & VARIABEL & METODOLOGI & HASIL \\
\hline 1 & $\begin{array}{l}\text { Marc Deloof, } \\
2003\end{array}$ & $\begin{array}{l}\text { Does Working Capital } \\
\text { Management Affect } \\
\text { Profitability of Belgian } \\
\text { Firms? }\end{array}$ & $\begin{array}{l}1.009 \text { perusahaan } \\
\text { besar non keuangan di } \\
\text { Belgia pada tahun } \\
1992-1996\end{array}$ & $\begin{array}{l}\text { Variabel independen : WCM } \\
\text { diukur dengan Cash } \\
\text { Convertion Cycle, jumlah hari } \\
\text { account s receivable, jumlah } \\
\text { hari inventory, jumlah hari } \\
\text { accounts payable } \\
\text { Variabel dependen : } \\
\text { Profitabilitas diukur dengan } \\
\text { gross operating income } \\
\text { Variabel kontrol : size } \\
\text { perusahaan, sales growth, } \\
\text { financial debt ratio dan ratio of } \\
\text { fixed financial assets to total } \\
\text { assets, net operating income }\end{array}$ & $\begin{array}{l}\text { Analisis Empirik, } \\
\text { analisis correlation } \\
\text { untuk menganalisis } \\
\text { korelasi koefisien } \\
\text { semua variabel, } \\
\text { analisis regression } \\
\text { untuk menganalisis } \\
\text { implikasi WCM pada } \\
\text { profitabilitas } \\
\text { perusahaan }\end{array}$ & $\begin{array}{l}\text { Hasil penelitian menunjukkan bahwa : 1) terdapat } \\
\text { hubungan yang negatif antara gross operating income } \\
\text { (profitabilitas) dengan jumlah hari accounts receivable, } \\
\text { inventory dan accounts payable (WCM) 2) koefisien } \\
\text { variabel accounts receivable negatif dan sangat signifikan } \\
\text { yang menyiratkan bahwa penambahan jumlah hari } \\
\text { account receivable selama } 1 \text { hari dapat menurunkan gross } \\
\text { operating income begitu pula variabel lainnya } \\
\text { berpengaruh sangat signifikan. Gross operating income } \\
\text { meningkat sejalan dengan size perusahaan, sales growth, } \\
\text { dan fix financial asset serta menurun sejalan dengan } \\
\text { financial debt 3) manajer dapat meningkatkan } \\
\text { profitabilitas perusahaan dengan mengurangi jumlah hari } \\
\text { accounts receivable dan inventory. Penjelasan mengenai } \\
\text { hubungan negatif antara account payable dan gross } \\
\text { operating income bahwa profit perusahaan akan berkurang } \\
\text { ketika mereka menunggu tagihan lebih lama dari biasanya }\end{array}$ \\
\hline 2 & $\begin{array}{l}\text { S.M.Amir Shah } \\
\text { dan Aisha Sana, } \\
2006\end{array}$ & $\begin{array}{l}\text { Impact of Working Capital } \\
\text { Management on the } \\
\text { Pofitability of Oil and Gas } \\
\text { Sector of Pakistan }\end{array}$ & $\begin{array}{l}11 \text { perusahaan minyak } \\
\text { dan gas Pakistan yang } \\
\text { terdaftar di Karachi } \\
\text { stock exchange pada } \\
\text { tahun 2001-2005 }\end{array}$ & $\begin{array}{l}\text { Variabel independen : WCM } \\
\text { diukur dengan Cash } \\
\text { Convertion Cycle, jumlah hari } \\
\text { account s receivable, jumlah } \\
\text { hari inventory, jumlah hari } \\
\text { accounts payable } \\
\text { Variabel dependen : } \\
\text { Profitabilitas diukur dengan } \\
\text { gross profit margin } \\
\text { Variabel kontrol : sales growth }\end{array}$ & $\begin{array}{l}\text { Analisis Empirik, } \\
\text { Correlation Analisis } \\
\text { dan Metode OLS } \\
\text { yang menggunakan } \\
\text { model Fixed Effect } \\
\text { Estimation }\end{array}$ & $\begin{array}{l}\text { Hasil penelitian menunjukkan bahwa : 1) terdapat } \\
\text { hubungan yang negatif antara gross profit margin dengan } \\
\text { jumlah hari inventory dan account receivable serta sales } \\
\text { growth } 2 \text { ) terdapat hubungan yang positif antara gross } \\
\text { profit margin dan jumlah hari accounts payable } 3 \text { ) efek } \\
\text { gabungan seluruh koefisien adalah signigikan yang berarti } \\
\text { working capital management memberikan efek pada } \\
\text { profitabilitas perusahaan }\end{array}$ \\
\hline 3 & $\begin{array}{l}\text { Vedavinayagam } \\
\text { Ganesan, } 2007\end{array}$ & $\begin{array}{l}\text { An Analysis Of Working } \\
\text { Capital Management } \\
\text { Efficiency In } \\
\text { Telecommunication } \\
\text { Equipment Industry }\end{array}$ & $\begin{array}{l}349 \text { perusahaan } \\
\text { perangkat } \\
\text { telekomunikasi di } \\
\text { Amerika pada tahun } \\
\text { 2001-2007 }\end{array}$ & $\begin{array}{l}\text { Variabel independen : WCM } \\
\text { diukur dengan Days of } \\
\text { Working Capital, days sales } \\
\text { outstanding, days inventory } \\
\text { outstanding, days payable } \\
\text { outstanding } \\
\text { Variabel dependen : } \\
\text { Profitabilitas diukur dengan } \\
\text { income to total asset dan } \\
\text { income to sales } \\
\text { Variabel kontrol : liquidity } \\
\text { diukur dengan cash convertion } \\
\text { efficiency dan current ratio }\end{array}$ & $\begin{array}{l}\text { analisis correlation } \\
\text { and regression untuk } \\
\text { menganalisis } \\
\text { hubungan WCM dan } \\
\text { profitabilitas, } \\
\text { ANOVA untuk } \\
\text { menganalisis dampak } \\
\text { WCM pada } \\
\text { profitabilitas }\end{array}$ & $\begin{array}{l}\text { Hasil penelitian menunjukkan bahwa : 1) terdapat } \\
\text { hubungan yang negatif antara efisiensi working capital } \\
\text { management dengan profitabilitas dan likuiditas 2) } \\
\text { efisiensi working capital management di industri } \\
\text { telekomunikasi rendah } 3 \text { ) industri telekomunikasi harus } \\
\text { meningkatkan efisiensi working capital management } \\
\text { dengan berkonsentrasi pada pengurangan inventory dan } \\
\text { meningkatkan DPO dengan mendapatkan lebih banyak } \\
\text { kredit dari pemasok }\end{array}$ \\
\hline
\end{tabular}




\begin{tabular}{|c|c|c|c|c|c|c|}
\hline NO & PENELITI & JUDUL & OBJEK & VARIABEL & METODOLOGI & HASIL \\
\hline 4 & $\begin{array}{l}\text { Pedro Juan } \\
\text { Garc1'a-Teruel } \\
\text { dan Pedro } \\
\text { Mart1'nez- } \\
\text { Solano, } 2007\end{array}$ & $\begin{array}{l}\text { Effects of working capital } \\
\text { management on SME } \\
\text { profitability }\end{array}$ & $\begin{array}{l}8,872 \text { UKM di } \\
\text { Spanyol pada tahun } \\
1996-2002\end{array}$ & $\begin{array}{l}\text { Variabel independen : WCM } \\
\text { diukur dengan cash convertion } \\
\text { cycle, jumlah hari accounts } \\
\text { receivable, inventory dan } \\
\text { accounts payable } \\
\text { Variabel dependen : } \\
\text { Profitabilitas diukur dengan } \\
\text { return of assets } \\
\text { Variabel kontrol : size } \\
\text { perusahaan, sales growth, } \\
\text { leverage }\end{array}$ & $\begin{array}{l}\text { metodologi panel } \\
\text { data }\end{array}$ & $\begin{array}{l}\text { Hasil penelitian menunjukkan bahwa : 1) terdapat } \\
\text { hubungan yang negatif antara profitabilitas UKM dengan } \\
\text { jumlah hari accounts receivable dan inventory 2) tidak ada } \\
\text { hubungan yang signifikan antara jumlah hari account } \\
\text { payable dengan pengembalian aset UKM 3) UKM harus } \\
\text { memperhatikan working capital management karena dapat } \\
\text { menciptakan nilai dengan mengurangi cash convertion } \\
\text { cycle hingga minimun sejauh masih masuk akal }\end{array}$ \\
\hline 5 & $\begin{array}{l}\text { Abdul } \\
\text { Raheman dan } \\
\text { Mohamed Nasr, } \\
2007\end{array}$ & $\begin{array}{l}\text { Working Capital } \\
\text { Management And } \\
\text { Profitability - Case Of } \\
\text { Pakistani Firms }\end{array}$ & $\begin{array}{l}94 \text { perusahaan non } \\
\text { keuangan Pakistan } \\
\text { yang terdaftar di } \\
\text { Karachi Stock } \\
\text { Exchangepada tahun } \\
1999 \text { - 2004 }\end{array}$ & $\begin{array}{l}\text { Variabel independen : WCM } \\
\text { diukur dengan cash convertion } \\
\text { cycle, average collection } \\
\text { period, inventory turnover in } \\
\text { days, average payment period } \\
\text { Variabel dependen : } \\
\text { Profitabilitas diukur dengan net } \\
\text { operating profitability } \\
\text { Variabel kontrol : liquidity } \\
\text { diukur dengan current ratio, } \\
\text { leverage diukur dengan size, } \\
\text { debt ratio, ratio of financial } \\
\text { assets to total assets }\end{array}$ & $\begin{array}{l}\text { Pearson's correlation } \\
\text { dan regression } \\
\text { analysis (Pooled least } \\
\text { square dan general } \\
\text { least square dengan } \\
\text { cross section weight } \\
\text { models) }\end{array}$ & $\begin{array}{l}\text { Hasil penelitian menunjukkan bahwa }: 1 \text { ) terdapat } \\
\text { hubungan yang negatif antara working capital } \\
\text { management (average collection period, inventory } \\
\text { turnover } \\
\text { in days, average payment period and cash conversion } \\
\text { cycle) dengan profitabilitas 2)perusahaan akan } \\
\text { mendapatkan profit yang meningkat apabila dapat } \\
\text { mengelola working capital secara baik }\end{array}$ \\
\hline 6 & $\begin{array}{l}\text { Melita } \\
\text { Stephanou } \\
\text { Charitou, Maria } \\
\text { Elfani, Petros } \\
\text { Lois, } 2010\end{array}$ & $\begin{array}{l}\text { The Effect Of Working } \\
\text { Capital Management On } \\
\text { Firm's Profitability: } \\
\text { Empirical Evidence From } \\
\text { An Emerging Market }\end{array}$ & $\begin{array}{l}43 \text { perusahaan non } \\
\text { keuangan yang } \\
\text { terdaftar di the Cyprus } \\
\text { Stock Exchange } \\
\text { periode tahun } 1998 \text { - } \\
2007\end{array}$ & $\begin{array}{l}\text { Variabel independen : WCM } \\
\text { diukur dengan cash convertion } \\
\text { cycle } \\
\text { Variabel dependen : } \\
\text { Profitabilitas diukur dengan } \\
\text { return of assets } \\
\text { Variabel kontrol : size, sales } \\
\text { growth dan debt ratio }\end{array}$ & $\begin{array}{l}\text { analisis multivariate } \\
\text { regression }\end{array}$ & $\begin{array}{l}\text { Hasil penelitian menunjukkan bahwa : 1) cash convertion } \\
\text { cycle terkait dengan profitabilitas perusahaan 2) efisiensi } \\
\text { pemanfaatan sumber daya perusahaan dapat } \\
\text { meningkatkan profitabilitas dan mengurangi volatilitas } \\
\text { yang mengarah pada penurunan resiko dan peningkatan } \\
\text { nilai perusahaan }\end{array}$ \\
\hline
\end{tabular}




\begin{tabular}{|c|c|c|c|c|c|c|}
\hline NO & PENELITI & JUDUL & OBJEK & VARIABEL & METODOLOGI & HASIL \\
\hline 7 & $\begin{array}{l}\text { David M. } \\
\text { Mathuva, } 2010\end{array}$ & $\begin{array}{l}\text { The Influence of Working } \\
\text { Capital Management } \\
\text { components on Corporate } \\
\text { Profitability : A Survey on } \\
\text { Kenyan Listed Firms }\end{array}$ & $\begin{array}{l}30 \text { perusahaan non } \\
\text { keuangan yang } \\
\text { terdaftar pada Nairobi } \\
\text { Stock Exchange } \\
\text { periode tahun } 1993- \\
2008\end{array}$ & $\begin{array}{l}\text { Variabel independen : WCM } \\
\text { diukur dengan cash convertion } \\
\text { cycle, accounts collection } \\
\text { period, inventory conversion } \\
\text { period, account payment period } \\
\text { Variabel dependen : } \\
\text { Profitabilitas diukur dengan net } \\
\text { operating profit } \\
\text { Variabel kontrol : size, sales } \\
\text { growth, GDP, the fix financial } \\
\text { asset ratio }\end{array}$ & $\begin{array}{l}\text { OLS dan the fixed } \\
\text { effects regression } \\
\text { models (pearson and } \\
\text { spearman corellation) }\end{array}$ & $\begin{array}{l}\text { Hasil penelitian menunjukkan bahwa : 1) terdapat } \\
\text { hubungan negatif dan signifikan antara accounts } \\
\text { collection period dan profitabilitas 2) terdapat hubungan } \\
\text { positif antara inventory conversion period dan } \\
\text { profitabilitas 3) terdapat hubungan yang positif dan } \\
\text { signifikan antara avarage payment period dan } \\
\text { profitabilitas }\end{array}$ \\
\hline 8 & $\begin{array}{l}\text { Nor Edi Azhar } \\
\text { Binti } \\
\text { Mohamad, } \\
\text { Noriza Binti } \\
\text { Mohd Saad, } \\
2010\end{array}$ & $\begin{array}{l}\text { Working Capital } \\
\text { Management: The Effect of } \\
\text { Market Valuation and } \\
\text { Profitability in Malaysia }\end{array}$ & $\begin{array}{l}172 \text { perusahaan yang } \\
\text { terdaftar di Bursa } \\
\text { Malaysia periode } \\
\text { tahun } 2003-2007\end{array}$ & $\begin{array}{l}\text { Variabel independen : WCM } \\
\text { diukur dengan cash convertion } \\
\text { cycle, current ratio, current } \\
\text { asset to total asset ratio, current } \\
\text { lianilities to total asset ratio, } \\
\text { debt to asset ratio } \\
\text { Variabel dependen : } \\
\text { Profitabilitas diukur dengan } \\
\text { return on asset dan return on } \\
\text { invested capital, market value } \\
\text { diukur dengan Tobin Q }\end{array}$ & $\begin{array}{l}\text { correlations dan } \\
\text { multiple regression } \\
\text { analysis }\end{array}$ & $\begin{array}{l}\text { Hasil penelitian menunjukkan bahwa : 1) ada hubungan } \\
\text { yang signifikan positif antara CATAR dengan Tobin Q, } \\
\text { ROA dan ROIC 2) CCC, CACLR dan CLTAR memiliki } \\
\text { hubungan signifikan negatif dengan Tobin Q, ROA dan } \\
\text { ROIC 3) DR memiliki hubungan signifikan negatif } \\
\text { dengan ROA, tidak memiliki hubungan signifikan dengan } \\
\text { ROIC dan memiliki hubungan signifikan positif dengan } \\
\text { Tobin Q }\end{array}$ \\
\hline 9 & $\begin{array}{l}\text { A.K. Sharma, } \\
\text { Satish Kumar, } \\
2011\end{array}$ & $\begin{array}{l}\text { Effect of Working Capital } \\
\text { Management on Firm } \\
\text { Profitability: } \\
\text { Empirical Evidence from } \\
\text { India }\end{array}$ & $\begin{array}{l}263 \text { perusahaan non } \\
\text { keuangan yang } \\
\text { terdaftar di Bombay } \\
\text { Stock (BSE) periode } \\
\text { tahun } 2000-2008\end{array}$ & $\begin{array}{l}\text { Variabel independen : WCM } \\
\text { diukur dengan cash convertion } \\
\text { cycle, jumlah hari account s } \\
\text { receivable, jumlah hari } \\
\text { inventory, jumlah hari accounts } \\
\text { payable } \\
\text { Variabel dependen : } \\
\text { Profitabilitas diukur dengan } \\
\text { return on asset } \\
\text { Variabel kontrol : size, sales } \\
\text { growth, leverage dan current } \\
\text { ratio }\end{array}$ & $\begin{array}{l}\text { OLS multiple } \\
\text { regression }\end{array}$ & $\begin{array}{l}\text { Hasil penelitian menunjukkan bahwa : 1) working capital } \\
\text { management dan profitabilitas berkorelasi positif di } \\
\text { perusahaan india 2) jumlah hari inventory dan jumlah hari } \\
\text { account payable berkorelasi negatif dengan profitabilitas } \\
\text { perusahaan 3) jumlah hari account payable dan cash } \\
\text { conversion cycle memiliki hubungan positif dengan } \\
\text { profitabilitas perusahaan }\end{array}$ \\
\hline 10 & $\begin{array}{l}\text { Mohammad } \\
\text { Alipour, } 2011\end{array}$ & $\begin{array}{l}\text { Working Capital } \\
\text { Management and } \\
\text { Corporate Profitability: } \\
\text { Evidence from Iran }\end{array}$ & $\begin{array}{l}1063 \text { firms from } 2001- \\
2006 \text { in Tehran stock } \\
\text { exchange. }\end{array}$ & $\begin{array}{l}\text { Variabel independen : WCM } \\
\text { diukur dengan cash convertion } \\
\text { cycle, Average Collection } \\
\text { Period (ACP), Inventory } \\
\text { Turnover in Days (ITID), } \\
\text { Average Payment Period }\end{array}$ & $\begin{array}{l}\text { multiple regression } \\
\text { and Pearson's } \\
\text { correlation }\end{array}$ & $\begin{array}{l}\text { Hasil penelitian menunjukkan bahwa : ada hubungan yang } \\
\text { signifikan antara working capital management dengan } \\
\text { profitabilitas dan working capital management memiliki } \\
\text { efek besar pada profitabilitas perusahaan }\end{array}$ \\
\hline
\end{tabular}




\begin{tabular}{|c|c|c|c|c|c|c|}
\hline NO & PENELITI & JUDUL & OBJEK & VARIABEL & METODOLOGI & HASIL \\
\hline & & & & $\begin{array}{l}\text { (APP) } \\
\text { Variabel dependen : } \\
\text { Profitabilitas diukur dengan } \\
\text { Gross Operation Profit } \\
\text { Variabel kontrol : Liquidity } \\
\text { (CR), The Company Size } \\
\text { (LOS), Financial Assets } \\
\text { (FATA), Debt Ratio (DR) }\end{array}$ & & \\
\hline 11 & $\begin{array}{l}\text { Zafar Ullah } \\
\text { Malik dan } \\
\text { Athar Iqbal, } \\
2012\end{array}$ & $\begin{array}{l}\text { Affect of Working Capital } \\
\text { Management } \\
\text { on Firms Profitability in } \\
\text { Sugar Industry } \\
\text { of Pakistan }\end{array}$ & $\begin{array}{l}19 \text { pabrik gula yang } \\
\text { terdaftar di Karachi } \\
\text { Stock Exchange dari } \\
\text { tahun } 1999-2009\end{array}$ & $\begin{array}{l}\text { Variabel independen : WCM } \\
\text { diukur dengan cash convertion } \\
\text { cycle, no of days inventory, no } \\
\text { of days accounts receivable, no } \\
\text { of days accounts payable } \\
\text { Variabel dependen : } \\
\text { Profitabilitas diukur dengan net } \\
\text { operating income } \\
\text { Variabel kontrol : Sales } \\
\text { growth, liquidity, leverage }\end{array}$ & $\begin{array}{l}\text { Pearson Correlation } \\
\text { and Multiple Linear } \\
\text { Regression }\end{array}$ & $\begin{array}{l}\text { Hasil penelitian menunjukkan bahwa : sales growth, } \\
\text { current ratio, jumlah hari inventory dan jumlah hari } \\
\text { accounts payable memiliki pengaruh yang signifikan } \\
\text { terhadap profitabilitas perusahaan sementara sales, } \\
\text { gearing ratio dan jumlah hari account receivable tidak } \\
\text { berpengaruh secara signifikan }\end{array}$ \\
\hline 12 & $\begin{array}{l}\text { Olayinka } \\
\text { Olufisayo } \\
\text { Akinlo, } 2012\end{array}$ & $\begin{array}{l}\text { Effect of Working Capital } \\
\text { on Profitability of Selected } \\
\text { Quoted } \\
\text { Firms in Nigeria }\end{array}$ & $\begin{array}{l}66 \text { perusahaan non } \\
\text { keuangan Nigeria } \\
\text { periode tahun } 1997- \\
2007\end{array}$ & $\begin{array}{l}\text { Variabel independen : WCM } \\
\text { diukur dengan cash convertion } \\
\text { cycle, ratio accounts } \\
\text { receivable, inventory days, } \\
\text { average payment period } \\
\text { Variabel dependen : } \\
\text { Profitabilitas diukur dengan } \\
\text { return of total assets } \\
\text { Variabel kontrol : size, the } \\
\text { sales growth and leverage }\end{array}$ & $\begin{array}{l}\text { OLS multiple } \\
\text { regression }\end{array}$ & $\begin{array}{l}\text { Hasil penelitian menunjukkan bahwa : 1) working capital } \\
\text { requirement berkolerasi positif dengan profitabilitas 2) } \\
\text { koefisien account receivable memiliki korelasi negatif } \\
\text { walaupun tidak signifikan 3) hubungan negatif yang } \\
\text { signifikan antara profitabilitas dengan jumlah hari } \\
\text { inventories 4) hubungan negatif antara profitabilitas } \\
\text { dengan jumlah hari account payable }\end{array}$ \\
\hline 13 & $\begin{array}{l}\text { Kulkanya } \\
\text { Napompech, } \\
2012\end{array}$ & $\begin{array}{l}\text { Effects of Working Capital } \\
\text { Management on the } \\
\text { Profitability of Thai Listed } \\
\text { Firms }\end{array}$ & $\begin{array}{l}255 \text { companies listed } \\
\text { on the Stock Exchange } \\
\text { of Thailand from } 2007 \\
\text { through } 2009\end{array}$ & $\begin{array}{l}\text { Variabel independen : WCM } \\
\text { diukur dengan cash convertion } \\
\text { cycle, the receivables } \\
\text { collection period, the inventory } \\
\text { conversion period, and the } \\
\text { payables deferral period } \\
\text { Variabel dependen : } \\
\text { Profitabilitas diukur dengan } \\
\text { Gorss operating profit } \\
\text { Variabel kontrol : firm size, } \\
\end{array}$ & $\begin{array}{l}\text { correlation, } \\
\text { regression analysis }\end{array}$ & $\begin{array}{l}\text { Hasil penelitian menunjukkan bahwa : adanya hubungan } \\
\text { negatif antara gross operating profit dengan inventory } \\
\text { conversin period dan receivable collection period }\end{array}$ \\
\hline
\end{tabular}




\begin{tabular}{|c|c|c|c|c|c|c|}
\hline NO & PENELITI & JUDUL & OBJEK & VARIABEL & METODOLOGI & HASIL \\
\hline & & & & $\begin{array}{l}\text { fixed financial asset ratio, The } \\
\text { debt ratio }\end{array}$ & & \\
\hline 14 & $\begin{array}{l}\text { Sayeda } \\
\text { Tahmina } \\
\text { Quayyum, } 2012\end{array}$ & $\begin{array}{l}\text { Relationship between } \\
\text { Working Capital } \\
\text { Management and } \\
\text { Profitability in Context of } \\
\text { Manufacturing Industries } \\
\text { in Bangladesh }\end{array}$ & $\begin{array}{l}28 \text { perusahaan yang } \\
\text { terdaftar di the Dhaka } \\
\text { Stock Exchange } \\
\text { periode } 2005-2009\end{array}$ & $\begin{array}{l}\text { Variabel independen : WCM } \\
\text { diukur dengan cash convertion } \\
\text { cycle, the receivables } \\
\text { collection period, the inventory } \\
\text { conversion period, and the } \\
\text { payables deferral period } \\
\text { Variabel dependen : } \\
\text { Profitabilitas diukur dengan } \\
\text { return on assets dan net profit } \\
\text { margin } \\
\text { Variabel kontrol : current ratio } \\
\text { dan quick ratio }\end{array}$ & regression analysis & $\begin{array}{l}\text { Hasil penelitian menunjukkan bahwa : 1) selain untuk } \\
\text { industri makanan, seluruh industri memiliki tingkat } \\
\text { signifikan hubungan antara indeks profitabilitas dan } \\
\text { berbagai komponen working capital 2) tingkat signifikansi } \\
\text { yang beragam dari industri ke industri lainnya }\end{array}$ \\
\hline 15 & $\begin{array}{l}\text { Salla } \\
\text { Marttonen, Sari } \\
\text { Monto and } \\
\text { Timo Ka“"rri, } \\
2013\end{array}$ & $\begin{array}{l}\text { Profitable working capital } \\
\text { management in industrial } \\
\text { maintenance companies }\end{array}$ & $\begin{array}{l}18 \text { perusahaan industri } \\
\text { pemeliharaan di } \\
\text { Finlandia periode } \\
\text { tahun } 20042008\end{array}$ & $\begin{array}{l}\text { FAM Model } \\
\text { Variabel independen : WCM } \\
\text { diukur dengan cash conversion } \\
\text { cycle, days inventories } \\
\text { outstanding, days sales } \\
\text { outstanding, days payables } \\
\text { outstanding } \\
\text { Variabel dependen : } \\
\text { Profitabilitas diukur dengan } \\
\text { return on investment } \\
\text { Variabel kontrol : fixed asset, } \\
\text { EBITDA }\end{array}$ & $\begin{array}{l}\text { analisis empirikal } \\
\text { dan analitikal } \\
\text { modeling }\end{array}$ & $\begin{array}{l}\text { Hasil penelitian menunjukkan bahwa : adanya korelasi } \\
\text { negatif yang signifikan antara cycle times of operational } \\
\text { working capital dan the return on investment }\end{array}$ \\
\hline 16 & $\begin{array}{l}\text { Venancio } \\
\text { Tauringana and } \\
\text { Godfred } \\
\text { Adjapong } \\
\text { Afrifa, } 2013\end{array}$ & $\begin{array}{l}\text { The relative importance of } \\
\text { working capital } \\
\text { management and its } \\
\text { components to SMEs' } \\
\text { profitability }\end{array}$ & $\begin{array}{l}19 \text { UKM yang } \\
\text { terdaftar di } \\
\text { Alternative Investment } \\
\text { Market (AIM) periode } \\
\text { tahun } 2005 \text { - } 2009\end{array}$ & $\begin{array}{l}\text { Variabel independen : WCM } \\
\text { diukur dengan the cash } \\
\text { conversion cycle (CCC), and } \\
\text { inventory, accounts receivable } \\
\text { and accounts payable } \\
\text { Variabel dependen : } \\
\text { Profitabilitas diukur dengan } \\
\text { return on assets } \\
\text { Variabel kontrol : quick ratio, } \\
\text { inventory to current asset, } \\
\text { current asset to total asset, } \\
\text { fixed asset to total asset, }\end{array}$ & $\begin{array}{l}\text { analisis regresi panel } \\
\text { data dan } \\
\text { survey kuesioner }\end{array}$ & $\begin{array}{l}\text { Hasil penelitian menunjukkan bahwa : } 1 \text { ) account payable } \\
\text { dan account receivable sangat penting bagi profitabilitas } \\
\text { UKM, namun account payable management relatif lebih } \\
\text { penting dibandingkan account receivable management 2) } \\
\text { inventory dan CCC management tidak penting bagi } \\
\text { profitabilitas UKM }\end{array}$ \\
\hline
\end{tabular}




\begin{tabular}{|c|c|c|c|c|c|c|}
\hline NO & PENELITI & JUDUL & OBJEK & VARIABEL & METODOLOGI & HASIL \\
\hline & & & & $\begin{array}{l}\text { current asset turnover, } \\
\text { leverage, logaritma total asset }\end{array}$ & & \\
\hline 17 & $\begin{array}{l}\text { Daniel Mogaka } \\
\text { Makori, } \\
\text { Ambrose } \\
\text { Jagongo , } 2013\end{array}$ & $\begin{array}{l}\text { Working Capital } \\
\text { Management and Firm } \\
\text { Profitability: Empirical } \\
\text { Evidence from } \\
\text { Manufacturing and } \\
\text { Construction Firms Listed } \\
\text { on Nairobi Securities } \\
\text { Exchange, Kenya }\end{array}$ & $\begin{array}{l}10 \text { perusahaan yang } \\
\text { terdaftar di NSE } \\
\text { periode tahun 2003- } \\
2012\end{array}$ & $\begin{array}{l}\text { Variabel independen : WCM } \\
\text { diukur dengan the cash } \\
\text { conversion cycle (CCC), } \\
\text { Average Collection Period, } \\
\text { Inventory Conversion Period, } \\
\text { Average Payment Period } \\
\text { Variabel dependen : } \\
\text { Profitabilitas diukur dengan } \\
\text { return on assets } \\
\text { Variabel kontrol : Sales } \\
\text { Growth, Firm Leverage, } \\
\text { Current Ratio, Firm Size }\end{array}$ & $\begin{array}{l}\text { Pearson's correlation } \\
\text { dan Ordinary Least } \\
\text { Squares regression } \\
\text { models }\end{array}$ & $\begin{array}{l}\text { Hasil penelitian menunjukkan bahwa : } 1 \text { ) adanya } \\
\text { hubungan negatif antara profitabilitas dengan jumlah hari } \\
\text { account receivable dan cash conversion cycle tetapi ada } \\
\text { hubungan positif antara profitabilitas dengan jumlah hari } \\
\text { inventory dan jumlah hari account payable } 2 \text { ) leverage, } \\
\text { sales growth, current ratio dan size perusahaan juga } \\
\text { memiliki efek signifikan terhadap profitabilitas } \\
\text { perusahaan }\end{array}$ \\
\hline 18 & $\begin{array}{l}\text { Dr. Mohammad } \\
\text { Fawzi Shubita, } \\
2013\end{array}$ & $\begin{array}{l}\text { Working Capital } \\
\text { Management and } \\
\text { Profitability: A Case of } \\
\text { Industrial Jordanian } \\
\text { Companies }\end{array}$ & $\begin{array}{l}39 \text { perusahaan yang } \\
\text { terdaftar di Amman } \\
\text { Stock Exchange pada } \\
\text { tahun 2004-2011 }\end{array}$ & $\begin{array}{l}\text { Variabel independen : WCM } \\
\text { diukur dengan Net Trade } \\
\text { Cycle, Days Receivable, Days } \\
\text { Inventory, Days Payable } \\
\text { ditambah Sales Growth } \\
\text { Variabel dependen : } \\
\text { Profitabilitas diukur dengan } \\
\text { return on assets }\end{array}$ & $\begin{array}{l}\text { analisis correlations } \\
\text { and multiple } \\
\text { regression }\end{array}$ & $\begin{array}{l}\text { Hasil penelitian menunjukkan bahwa : adanya kaitan } \\
\text { secara negatif signifikan antara variabel working capital } \\
\text { dengan profitabilitas perusahaan sehingga menyoroti } \\
\text { pentingnya mengelola working capital untuk } \\
\text { meningkatkan profitabilitas perusahaan }\end{array}$ \\
\hline 19 & $\begin{array}{l}\text { Harsh Vineet } \\
\text { Kaur, Sukhdev } \\
\text { Singh, } 2013\end{array}$ & $\begin{array}{l}\text { Managing Working Capital } \\
\text { Efficiency in Capital } \\
\text { Goods Sector in India }\end{array}$ & $\begin{array}{l}14 \text { perusahaan sektor } \\
\text { barang modal dari } \\
\text { tahun } 2000-2001 \mathrm{ke} \\
2009-2010\end{array}$ & $\begin{array}{l}\text { Variabel independen dan } \\
\text { dependen diukur dengan } \\
\text { Performance Index, Utilization } \\
\text { Index and Efficiency Index of } \\
\text { Working Capital Management }\end{array}$ & $\begin{array}{l}\text { Analisis Empirik, } \\
\text { Pearson Correlation }\end{array}$ & $\begin{array}{l}\text { Hasil penelitian menunjukkan bahwa : adanya hubungan } \\
\text { antara efisiensi working capital management dengan } \\
\text { profitabilitas yang telah ditetapkan dengan menghitung } \\
\text { korelasi antara efficiency index dan income to current } \\
\text { asset serta efisiensi index dan income to average total } \\
\text { assets }\end{array}$ \\
\hline 20 & $\begin{array}{l}\text { Hina Agha, } \\
2013\end{array}$ & $\begin{array}{l}\text { Impact Of Working Capital } \\
\text { Management On } \\
\text { Profitability }\end{array}$ & $\begin{array}{l}\text { perusahaan farmasi } \\
\text { Glaxo Smith } \\
\text { Kline yang terdaftar di } \\
\text { Karachi stock } \\
\text { exchange periode } \\
\text { tahhun 1996-2011 }\end{array}$ & $\begin{array}{l}\text { Variabel independen : WCM } \\
\text { diukur dengan debtors turnover } \\
\text { ratio, creditors turnover ratio, } \\
\text { current ratio, } \\
\text { Variabel dependen : } \\
\text { Profitabilitas diukur dengan } \\
\text { return on assets }\end{array}$ & $\begin{array}{l}\text { Coefficient, standard } \\
\text { error test, t-statistics, } \\
\text { Adjusted R-squared, } \\
\text { F-statistic, } \\
\text { Prob.(Fstatistic) dan } \\
\text { the Durbin-Watson } \\
\text { statistics }\end{array}$ & $\begin{array}{l}\text { Hasil penelitian menunjukkan bahwa : adanya hubungan } \\
\text { yang positif antara debtors turnover dan return on assets, } \\
\text { antara inventory turnover dan return on assets tetapi tidak } \\
\text { ada hubungan yang signifikan antara current ratio dan } \\
\text { return on asset }\end{array}$ \\
\hline
\end{tabular}




\begin{tabular}{|c|c|c|c|c|c|c|}
\hline NO & PENELITI & JUDUL & OBJEK & VARIABEL & METODOLOGI & HASIL \\
\hline 21 & $\begin{array}{l}\text { Richard Kofi } \\
\text { Akoto, Dadson } \\
\text { Awunyo-Vitor } \\
\text { and Peter } \\
\text { Lawer Angmor, } \\
2013\end{array}$ & $\begin{array}{l}\text { Working capital } \\
\text { management and } \\
\text { profitability: Evidence } \\
\text { from Ghanaian listed } \\
\text { manufacturing firms }\end{array}$ & $\begin{array}{l}13 \text { perusahaan } \\
\text { manufaktur di Gana } \\
\text { periode tahun } \\
2005-2009\end{array}$ & $\begin{array}{l}\text { Variabel independen : WCM } \\
\text { diukur dengan cash conversion } \\
\text { cycle, accounts payable days } \\
\text { Variabel dependen : } \\
\text { Profitabilitas diukur dengan } \\
\text { return on equity } \\
\text { Variabel kontrol : current ratio, } \\
\text { firm size }\end{array}$ & $\begin{array}{l}\text { metodologi data } \\
\text { panel }\end{array}$ & $\begin{array}{l}\text { Hasil penelitian menunjukkan bahwa : adanya hubungan } \\
\text { signifikan negatif antara profitabilitas dan accounts } \\
\text { receivable }\end{array}$ \\
\hline 22 & $\begin{array}{l}\text { Shaista } \\
\text { Wasiuzzaman, } \\
2015\end{array}$ & $\begin{array}{l}\text { Working Capital and } \\
\text { Profitability in } \\
\text { Manufacturing Firms in } \\
\text { Malaysia: An Empirical } \\
\text { Study }\end{array}$ & $\begin{array}{l}160 \text { perusahaan } \\
\text { manufaktur di } \\
\text { Malaysia }\end{array}$ & $\begin{array}{l}\text { Variabel independen : WCM } \\
\text { diukur dengan Inventory } \\
\text { (INV), Receivables (REC), } \\
\text { Payables (PAY) } \\
\text { Variabel dependen : } \\
\text { Profitabilitas diukur dengan } \\
\text { return on assets } \\
\text { Variabel kontrol : Growth, } \\
\text { Size, Leverage (LEV), Gross } \\
\text { Domestic Product (GDP) }\end{array}$ & $\begin{array}{l}\text { teknik ordinary least } \\
\text { squares (OLS) } \\
\text { regression }\end{array}$ & $\begin{array}{l}\text { Hasil penelitian menunjukkan bahwa : 1) adanya } \\
\text { hubungan negatif antara working capital (dan } \\
\text { komponennya) dengan profitabilitas, selain untuk } \\
\text { hubungan negatif antara payables dengan profitabilitas, } \\
\text { hubungan lainnya mengikuti harapan umum berdasarkan } \\
\text { teori keuangan populer } 2 \text { ) adanya hubungan working } \\
\text { capital (dan komponennya) dengan profitabilitas mungkin } \\
\text { tidak semudah kelihatannya dan mungkin tergantung pada } \\
\text { pengaruh lain seperti kebijakan ekonomi }\end{array}$ \\
\hline 23 & $\begin{array}{l}\text { Godfred } \\
\text { Adjappong } \\
\text { Afrifa, 2016 }\end{array}$ & $\begin{array}{l}\text { Net working capital, cash } \\
\text { flow and performance of } \\
\text { UK SMEs }\end{array}$ & $\begin{array}{l}6,926 \text { UKM non } \\
\text { keuangan di UK } \\
\text { periode tahun } 2004- \\
2013\end{array}$ & $\begin{array}{l}\text { Variabel independen : WCM } \\
\text { diukur dengan Net working } \\
\text { capital, Annual sales growth, } \\
\text { Operating cash flow, Cash } \\
\text { holdings } \\
\text { Variabel dependen : } \\
\text { Performance diukur dengan } \\
\text { return on assets dan Tobin Q } \\
\text { Variabel kontrol : annual sales } \\
\text { growth (GROWTH), firm age } \\
\text { (AGE), firm size (SIZE), } \\
\text { tangible fixed assets (ATAN) } \\
\text { and financial leverage (LEV) }\end{array}$ & $\begin{array}{l}\text { analisis unbalanced } \\
\text { panel data regression }\end{array}$ & $\begin{array}{l}\text { Hasil penelitian menunjukkan bahwa : 1) adanya } \\
\text { hubungan cekung yang kuat antara net working capital } \\
\text { dan performansi dengan tidak adanya cash flow, namun } \\
\text { hubungan menjadi cembung setelah memasukan cash flow } \\
\text { sebagai bahan pertimbangan 2) perusahaan dengan cash } \\
\text { flow berada dibawah median sampel menunjukkan } \\
\text { investasi yang lebih tinggi pada working capital 3) } \\
\text { manajer seharusnya mempertimbangkan cash flow ketika } \\
\text { menentukan investasi yang tepat dalam membentuk } \\
\text { working capital sehingga meningkatkan performansi }\end{array}$ \\
\hline
\end{tabular}




\begin{tabular}{|c|c|c|c|c|c|c|}
\hline NO & PENELITI & JUDUL & OBJEK & VARIABEL & METODOLOGI & HASIL \\
\hline 24 & $\begin{array}{l}\text { Godfred } \\
\text { Adjapong } \\
\text { Afrifa, } \\
\text { Kesseven } \\
\text { Padachi, } 2016\end{array}$ & $\begin{array}{l}\text { Working capital level } \\
\text { influence on SME } \\
\text { profitability }\end{array}$ & $\begin{array}{l}160 \text { UKM non } \\
\text { keuangan yang } \\
\text { terdaftar di Alternative } \\
\text { Investment Market } \\
\text { (AIM) London Stock } \\
\text { Exchange periode } \\
\text { tahun } 2005 \text { - } 2010\end{array}$ & $\begin{array}{l}\text { Variabel independen : WCM } \\
\text { diukur dengan Cash } \\
\text { Conversion Cycle dan CCC2 } \\
\text { Variabel dependen : } \\
\text { Performance diukur dengan } \\
\text { return on assets, return on } \\
\text { equity, return on capital } \\
\text { employed } \\
\text { Variabel kontrol : firm age } \\
\text { (COAGE), firm size } \\
\text { (COSIZE), asset tangibility } \\
\text { (ATAN), financial leverage } \\
\text { ratio (LEV), liquidity ratio } \\
\text { (LIQ), short-term financing } \\
\text { (SFIN) and industry } \\
\text { classification (INDUST) }\end{array}$ & $\begin{array}{l}\text { analisis reggression } \\
\text { panel-data }\end{array}$ & $\begin{array}{l}\text { Hasil penelitian menunjukkan bahwa : adanya hubungan } \\
\text { cekung antara tingkat working capital dan profitabilitas } \\
\text { perusahaan dan bahwa ada tingkat working capital yang } \\
\text { optimal ketika memaksimalkan profitabilitas perusahaan }\end{array}$ \\
\hline 25 & $\begin{array}{l}\text { Maria Amélia } \\
\text { Pais Paulo M } \\
\text { Gama, } 2015\end{array}$ & $\begin{array}{l}\text { Working capital } \\
\text { management and SMEs } \\
\text { profitability: Portuguese } \\
\text { evidence }\end{array}$ & $\begin{array}{l}6063 \text { UKM Portugis } \\
\text { periode tahun 2002- } \\
2009\end{array}$ & $\begin{array}{l}\text { Variabel independen : WCM } \\
\text { diukur dengan jumlah hari } \\
\text { accounts receivable, jumlah } \\
\text { hari accounts payable, jumlah } \\
\text { hari inventory, cash conversion } \\
\text { cycle } \\
\text { Variabel dependen : } \\
\text { Profitabilitas diukur dengan } \\
\text { return on assets (ROA) } \\
\text { Variabel kontrol : the size of } \\
\text { the firm (SIZE), the growth in } \\
\text { its sales (SGROW), leverage } \\
\text { (DEBT), current assets ratio } \\
\text { (CAR), current liabilities ratio } \\
\text { (CLR) }\end{array}$ & $\begin{array}{l}\text { metode analisis panel } \\
\text { data: ordinary least } \\
\text { squares (OLS), fixed } \\
\text { dan random effects }\end{array}$ & $\begin{array}{l}\text { Hasil penelitian menunjukkan bahwa : praktek kebijakan } \\
\text { working capital management yang lebih agresif } \\
\text { meningkatkan profitabilitas perusahaan }\end{array}$ \\
\hline
\end{tabular}




\section{Perusahaan berskala besar}

Jurnal-jurnal yang di review pada perusahaan yang terdaftar di Bursa Efek memiliki objek yang berasal dari berbagai negara dan paling banyak dari negaranegara Asia, seperti diperlihatkan pada tabel dibawah ini :

Tabel 1. Jurnal berdasarkan asal penelitian

\begin{tabular}{|c|c|c|c|}
\hline Benua & Negara & Jurnal & Total \\
\hline Amerika & Amerika Serikat & Ganesan, 2007 & 1 \\
\hline \multirow{7}{*}{ Asia } & Bangladesh & Quayyum, 2012 & \multirow{7}{*}{12} \\
\hline & India & Sharma dan Kumar, 2011; Kaur dan Singh, 2013 & \\
\hline & Iran & Alipour, 2011 & \\
\hline & Jordania & Shubita, 2013 & \\
\hline & Malaysia & Azhar dan Noriza, 2010; Wasiuzzaman, 2015 & \\
\hline & Pakistan & $\begin{array}{l}\text { Shah dan Sana, 2006; Raheman dan Nasr, 2007; } \\
\text { Malik dan Igbal, 2012; Agha, } 2013\end{array}$ & \\
\hline & Thailand & Napompech, 2012 & \\
\hline \multirow{3}{*}{ Afrika } & Ghana & Akoto, et al., 2013 & \multirow{3}{*}{4} \\
\hline & Kenya & Mathuva, 2010; Makori dan Jagongo, 2013 & \\
\hline & Nigeria & Akinlo, 2012 & \\
\hline \multirow{3}{*}{ Eropa } & Belgia & Deloof, 2003 & \multirow{3}{*}{3} \\
\hline & Cyprus & Charitou et al., 2010 & \\
\hline & Finlandia & Marttonen et al., 2013 & \\
\hline
\end{tabular}

Sumber : diolah penulis

Deloof (2003) melakukan penelitian pada 1.009 perusahaan di Belgia dan menemukan bahwa terdapat hubungan negatif yang signifikan antara gross operating income (profitabilitas) dengan jumlah account receivable juga inventory. Dia juga menemukan bahwa terdapat hubungan negatif antara siklus waktu account payable dengan profitabilitas perusahaan yang diikuti juga hasilnya oleh penelitian Sharma dan Kumar (2011), Wasiuzzaman (2015), Raheman dan Nasr (2007), Charitou et al, (2010), Azhar dan Noriza (2010), Napompech (2012), Quayyum (2012), Marttonen et al, (2013), Akoto et al, (2013).

Penelitian Akinlo (2012) dilakukan di 66 perusahaan non keuangan di Nigeria hampir sama hasilnya dengan penelitian Deloof (2003) tetapi yang memiliki hubungan negative yang signifikan dengan profitabilitas, bukan account receivable dan inventory melainkan account payable dan inventory diikuti juga hasilnya oleh penelitian Ganesan (2007), Alipour (2011), Shubita (2013).

Malik dan Iqbal (2012) meneliti 19 Pabrik Gula di Pakistan menunjukkan hasil bahwa terdapat hubungan negative yang signifikan antara net operating income (profitabilitas) dengan jumlah account receivable dan inventory Tetapi tidak ditemukan hubungan yang signifikan pada account payable dan net operating income.

Berbeda lagi dengan penelitian Shah dan Sana (2006) yang meneliti 11 perusahaan minyak dan gas di Pakistan menemukan bahwa terdapat hubungan yang negatif antara gross profit margin dengan jumlah hari inventory dan account receivable, tetapi ada hubungan yang positif antara gross profit margin dan jumlah hari accounts payable. Di lain pihak, penelitian Mathuva (2010) menemukan bahwa hubungan positif antara profitabilitas dengan inventory dan payable, sedangkan account receivable memiliki hubungan negative dengan profitabilitas sesuai dengan penelitian Deloof (2003), Garcia-Teruel dan Solano (2007), Shah dan Sana (2006). Penelitian Mathuva sama hasilnya dengan penelitian Makori dan Jangongo (2013), Agha (2013).

\section{Perusahaan kecil dan menengah (UKM)}

Objek UKM pada 5 jurnal yang direview berasal dari negara-negara eropa dimana 3 berasal dari Inggris (Tauringana dan Afrifa, 2013, Afrifa, 2016 dan Afrifa dan Pedachi, 2016) dan sisanya dari Spanyol (Garcia-Teruel dan Solano, 2007) dan Portugis (Gama, 2015).

Garcia-Teruel dan Solano (2007) menggunakan variabel yang sama dengan Deloof (2003) dan menemukan bahwa terdapat hubungan negatif yang signifikan antara ROA (profitabilitas) dengan jumlah account receivable dan inventory pada sampel data sebanyak 8.872 UKM di Spanyol. Tetapi Garcia-Teruel dan Solano (2007) menemukan bahwa tidak ada hubungan yang signifikan antara account payable dengan pengembalian asset UKM.

Tauringana dan Afrifa (2013) memiliki perbedaan hasil penelitian dengan Garcia-Teruel dan Solano (2007). Tauringana dan Afrifa 
menggunakan sampel 19 UKM di Alternative Investment Market (AIM), UK yang menunjukkan hasil account payable dan account receivable sangat penting bagi profitabilitas UKM, namun account payable management relatif lebih penting dibandingkan account receivable management serta inventory dan CCC management tidak penting bagi profitabilitas UKM.

Penelitian yang dilakukan oleh Gama (2015), Afrifa (2016) serta Afrifa dan Pedachi (2016) menunjukkan hasil bahwa tingkat working capital yang optimal dapat meningkatkan profitabilitas perusahaan.

\section{KESIMPULAN}

Berdasarkan literature review yang dilakukan pada 25 jurnal periode 20032016, diketahui bahwa terdapat hubungan antara working capital management (WCM) dengan profitabilitas perusahaan. Hasil yang diperoleh yaitu ada 10 jurnal yang memiliki hasil penelitian yang sama bahwa terdapat hubungan negatif yang signifikan antara gross operating income (profitabilitas) dengan jumlah account receivable juga inventory, juga menemukan bahwa terdapat hubungan negatif antara siklus waktu account payable dengan profitabilitas perusahaan. Oleh karena itu peneliti akan menggunakan hasil penelitian tersebut yang menggunakan objek perusahaan yang terdaftar di Bursa Efek menjadi sebuah hipotesis sebagai berikut :

H1 : terdapat hubungan yang signifikan antara gross operating income (profitabilitas) dengan jumlah account receivable

$\mathrm{H} 2$ : terdapat hubungan yang signifikan antara gross operating income (profitabilitas) dengan jumlah inventory

H3 : terdapat hubungan yang signifikan antara gross operating income (profitabilitas) dengan jumlah account payable
H3 : terdapat hubungan yang signifikan antara gross operating income (profitabilitas) dengan cash conversion cycle.

\section{DAFTAR PUSTAKA}

Afrifa G A (2016), Net working capital, cash flow and performance of UK SMEs ", Rev Acc and Finance, 15 (1) : $21-44$

Afrifa G A (2016), Working capital level influence on SME profitability, J. Small. Bus. Ent. Dev. 23 (1) : 44-63

Agha H, Mba, Mphil (2014), Impact of Working Capital Management on Profitability, Europan Sci. J., 10 (1): 374-381

Akoto R K, Vitor D A, Angmor P L (2013), Working capital management and profitability: Evidence from Ghanaian listed manufacturing firms, J. Econ. Int. Finance. 5 (9) : 373-379

Akinlo O O, (2012), Effect of Working Capital on Profitability of Selected Quoted Firms in Nigeria, Global Bus. Rev., 13 (3): 367:381

Alipour M, (2011), Working Capital Management and Corporate Profitability: Evidence from Iran, World. Appl. Sci. J., 12 (7): 10931099

Azhar N E, (2010), Working Capital Management: The Effect of_Market Valuation and Profitability in Malaysia, Int. J. Bus. Management,_5 (11): $140-147$

Charitou M S, Elfani M, Lois P (2010), The Effect of Working Capital Management on Firm's Profitability: Empirical Evidence From An Emerging Market, J. Bus. Eco and Res, 8 (12): 63-68

Deloof M (2003), Does Working Capital Management Affect Profitability of Belgian Firms, J. Bus. Finance and Acc, 30 (3) and (4): 573-587 
Ganesan V (2007), An Analysis of Working Capital Management Efficiency in Telecomunication Equipment Industry, Rivier. Academic. J, 3 (2) 1-10

Garcia P J, Martinez T P, Solano (2007), Effect of Working Capital Management on SME Profitability, Int. J. Man. Finance, 3 (2): 164-177

Kaur H V, Singh S, (2013) Managing Working Capital Efficiency in CapitalGoods Sector in India, Glo. Bus. Revi., 14 (2): 343-355

Makori D M, Jagongo A (2013), Working Capital Management and Firm Profitability: Empirical Evidence from Manufacturing and Construction Firms Listed on Nairobi Securities Exchange, Kenya, Int, J, Acc Tax, 1 (1)

Malik Z M, Iqbal A, (2012), Affect of working Capital Management on Firms Profitability in Sugar Industry of Pakistan, MPRA. 41436 (19): 1-29

Marttonen S, Monto S, Karri T, (2013), Profitability Working Capital Management in Industrial Manitenance Companies, J. Emerald Insight., : 429-446

Mathuva D M (2010), The Influence of Working Capital Management Components on Corporate Profitability: A Survey on Kenyan Listed Firms, Res. J. Bus. Management 4 (1): 1-11

Napompech K, (2012), Effects of Working Capital Management on the Profitability of Thai Listed Firms, Int. J. Trade. Eco. Finance., 3 (3): 227 232

Pais M A, Gama P M, (2015), Working Capital Management and SMEs Profitability: Portuguese Evidence, Int. J. Managerial. Finance., 11 (3): 119
Quayyum S T, (2012), Relationship Between Working Capital Management and Profitability in Context of Manufacturing Industries in Bangladesh, Int. J. Bus. Management., 7 (1): 58-69

Raheman A, Nasr M (2007), Working Capital management and Profitability: Case of Pakistan Films, Int, Rev. Bus. Res. Papers. 3 (1): 279 300

Shah S A, Sana A (2006), Impact of Working Manajement on the Profitability of oil and Gas Sector of Pakistan, Europan. J. Sci. Res., 15 (3):301-307

Sharma A K, Kumar S (2011), Effect of Working Capital Management on Firm Profitability: Empirical Evidence from India, Global. Bus. Rev., 12 (1): 159-173

Shubita M F (2013), Working Capital Management and Profitability: A Case of Industrial Jordanian Companies, Int. J. Bus. Soc. Sci. 4 (8): 108-115

Tauringana V, Afrifa G P, (2013), The Relative Importance of Working Capital Management and its Components to SMEs' Profitability, Dep. Acc. Finance. Eco., 20 (3) :453469

Wasiuzzaman S (2015), Working Capital and Profitability in Manufacturing Firms in Malaysia: An Empirical Study, Glo. Bus. Rev, 16 (4): 545-556 